\title{
Synthesis, Biological Evaluation and Molecular Docking of Avicequinone C Analogues as Potential Steroid $\mathbf{5} \alpha$-Reductase Inhibitors
}

\author{
Wiranpat Karnsomwan, ${ }^{a}$ Ponsawan Netcharoensirisuk, ${ }^{a}$ Thanyada Rungrotmongkol, ${ }^{b}$ \\ Wanchai De-Eknamkul, ${ }^{a}$ and Supakarn Chamni*,a \\ ${ }^{a}$ Department of Pharmacognosy and Pharmaceutical Botany, Faculty of Pharmaceutical Sciences, Chulalongkorn \\ University; 254 Phayathai Road, Pathumwan, Bangkok 10330, Thailand: and ${ }^{b}$ Structural and Computational Biology \\ Research Group, Department of Biochemistry, and Ph.D. Program in Bioinformatics and Computational Biology, \\ Faculty of Science, Chulalongkorn University; 254 Phayathai Road, Pathumwan, Bangkok 10330, Thailand. \\ Received September 13, 2016; accepted December 25, 2016
}

\begin{abstract}
Avicequinone C (5a), a furanonaphthoquinone isolated from the Thai mangrove Avicennia marina has been shown previously to have interesting steroid $5 \alpha$-reductase type 1 inhibitory activity. In this study, a series of avicequinone $C$ analogues containing furanonaphthoquinone with different degrees of saturation and substituents at the furan ring were synthesized. The resulting synthetic avicequinone $C$ and analogues (5a-f) along with some related compounds including 2,5-dihydroxy-1,4-benzoquinone (6) and natural naphthoquinones such as lawsone (7a) and lapachol (7b) were evaluated for their in vitro cell viability and steroid $5 \alpha$-reductase type 1 inhibitory activities using the cultured cell line of human keratinocytes (HaCaT). This cell-based bioassay was performed based on a direct detection of the enzymatic product dihydrotestosterone (2) by using a non-radioactive high performance thin layer chromatography (HPTLC) method. Among the furanonaphthoquinones in this series, 5e having a propionic substituent at furan ring possessed approximately 22-fold more potent than the original isolated compound 5a. However, the compounds without furan motif such as $6,7 \mathrm{a}$ and $b$ could not inhibit the activity of steroid $5 \alpha$-reductase. Molecular docking results of the in silico three-dimensional steroid $5 \alpha$-reductase type 1-reduced nicotinamide adenine dinucleotide phosphate (NADPH) binary complex was performed via AutoDock Vina and it illustrated that the furanonaphthoquinone moiety and the substituent at furan ring might play a key role as pharmacophores for the steroid $5 \alpha$-reductase inhibitory activity.
\end{abstract}

Key words furanonaphthoquinone; avicequinone $\mathrm{C}$ analogue; steroid $5 \alpha$-reductase inhibitor; dihydrotestosterone; androgenic alopecia

Steroid $5 \alpha$-reductase is a membrane bound enzyme in the oxidoreductase family, which controls the biological actions in steroid metabolism. ${ }^{1,2)}$ Presently, three isozymes of this enzyme are known and their amino acid sequence similarity has been analyzed and compared. ${ }^{3)}$ The steroid $5 \alpha$-reductase type 1 is mainly found in the scalp, non-genital skin, sebaceous gland and liver, while steroid $5 \alpha$-reductase type 2 is specifically locates in the prostate gland, testis, epididymis and scrotum. ${ }^{4,5)}$ Steroid $5 \alpha$-reductase type 3 , on the other hand, has been reported in benign and malignant tissues. ${ }^{6}$ Physiologically, the overexpression of steroid $5 \alpha$-reductase, especially types 1 and 2, is believed to affect the balance between testosterone (1) and dihydrotestosterone (2), and such imbalance is implicated in androgenic disorders, including prostate cancer, hirsutism and androgenic alopecia. ${ }^{7)}$

Androgenic alopecia is described as a form of scalp-hair loss caused by decreasing the growth of hair, which may lead to baldness. ${ }^{8,9)}$ This symptom can happen in both male and female, although the severity and frequency are greater in men than women and in some specific ethnic groups. The causes of androgenic alopecia are genetically related, causing some physical disorders that lead to the overproduction of $5 \alpha$-dihydrotestosterone. ${ }^{10)}$ The most common prescribed drugs for androgenic alopecia treatment are finasteride (3), which is a steroid $5 \alpha$-reductase type 2 inhibitor, ${ }^{11,12}$ and dutasteride (4), which is an effective inhibitor to both $5 \alpha$-reductase types 1 and $2^{13-15)}$ (Chart 1). Currently, there have been several reports on the discovery and development of new steroid $5 \alpha$-reductase inhibitors for baldness treatment, including steroid and non-steroid analogues. ${ }^{9,16)}$ However, most of the reported $5 \alpha$-reductase inhibitors have not been designed specifically for the inhibition of steroid $5 \alpha$-reductase at the catalytic site, due to the lack of a single X-ray crystal structure, which has hindered a mechanistic understanding and delayed the discovery and development of an effective inhibitor. Thus, several in silico structures of steroid $5 \alpha$-reductase have recently been reported to use as a surrogate structure in the screening of potential inhibitors of this enzyme. ${ }^{17-19)}$

Previously, it was reported that avicequinone C (5a), a furanonaphthoquinone, isolated from the methanolic extract of Avicennia marina, could inhibit the activity of steroid $5 \alpha$-reductase type 1 at a micromolar scale $\left(\mathrm{IC}_{50}=38.8 \mu \mathrm{M}\right)$. This finding was based on the use of a newly developed nonradioactive human hair dermal papilla cell-based assay, which directly detects dihydrotestosterone (DHT, 2), the enzymatic product, by high performance thin layer chromatography (HPTLC). ${ }^{20,21)}$ Even though the steroid $5 \alpha$-reductase inhibitory activity of 5a was not as potent as dutasteride (4), the discovery of a new chemical scaffold has provided a potential for the development of a new group of steroid $5 \alpha$-reductase inhibitors. Thus, we hypothesized that compounds having a furanonaphthoquinone, similar to $\mathbf{5 a}$ and a more simplified structure, naphthoquinone, would be used as the potential steroid $5 \alpha$-reductase inhibitors. 


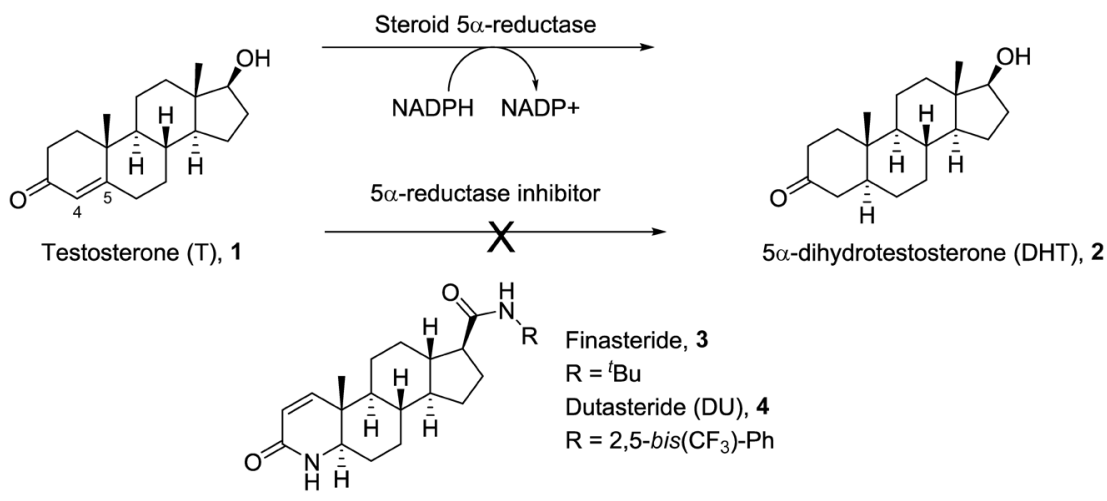

Chart 1. Inhibition of Steroid $5 \alpha$-Reductase

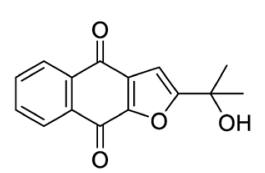

avicequinone $C, 5 a$<smiles>CC(C)(O)C1CC2=C(O1)C(=O)c1ccccc1C2=O</smiles><smiles>O=C1C=C(O)C(=O)C=C1O</smiles>

6<smiles>CC(=O)c1cc2c(o1)C(=O)c1ccccc1C2=O</smiles>

5b


$7 a$

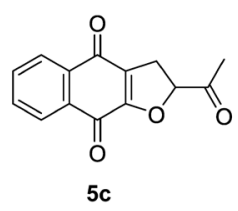<smiles>O=C1c2ccccc2C(=O)c2occc21</smiles><smiles>CC(C)=CCC1=C(O)C(=O)c2ccccc2C1=O</smiles>

$7 \mathbf{b}$

Chart 2. Avicequinone C Analogues (5a-f), Quinone 6 and Naphthoquinones $7 \mathbf{a}$ and $\mathbf{b}$ as Potential Steroid $5 \alpha$-Reductase Inhibitors

In this study, we focused on the synthesis and biological study of potential steroid $5 \alpha$-reductase inhibitors from a series of avicequinone $\mathrm{C}$ analogues $(\mathbf{5 a} \mathbf{a}-\mathbf{f})$ that contain different degrees of saturation and substituents at the furan ring. The structural related compounds including 2,5-dihydroxy-1,4benzoquinone (6) along with natural naphthoquinones such as lawsone (2-hydroxy-1,4-naphthoquinone, 7a) and lapachol (2-hydroxy-3-(3-methylbut-2-enyl)naphthalene-1,4-dione, 7b) were employed to investigate the assumption about the importance of the furanonaphthoquinone moiety in the inhibition of steroid $5 \alpha$-reductase type 1 (Chart 2). Avicequinone $\mathrm{C}$ and analogues (5a-f) were synthesized from lawsone (7a) by chemical transformations involving the two-step-one-pot Michael- $O$-alkylation followed by methylation. The resulting synthetic furanonaphthoquinones analogues $\mathbf{5 a - f}$, quinone $\mathbf{6}$, and naphthoquinones $7 \mathbf{a}$ and $\mathbf{b}$ were then evaluated for their in vitro cytotoxicity and steroid $5 \alpha$-reductase inhibitory activities using $\mathrm{HaCaT}$, a human keratinocyte cell line. This cell line has been shown to be a source of testosterone (1) metabolism ${ }^{22,23)}$ and to have steroid $5 \alpha$-reductase type 1 expression. ${ }^{24)}$ Thus, the $\mathrm{HaCaT}$ cell line could serve as a general cell-based assay for the study of steroid $5 \alpha$-reductase inhibition. The steroid $5 \alpha$-reductase inhibition was measured based on the amount of dihydrotestosterone (2) produced, determined using HPTLC as previously described. ${ }^{20,21)}$ Molecular docking using the

homologous protein template of steroid $5 \alpha$-reductase type $1^{19)}$ was performed via AutoDock Vina ${ }^{25)}$ to predict the biomolecular interaction between the $5 \alpha$-reductase-reduced nicotinamide adenine dinucleotide phosphate (NADPH) binary complex and the respective furanonaphthoquinones. Herein, an essential pharmacophore and inhibitory activity of a potential steroid $5 \alpha$-reductase inhibitor are discussed.

\section{Results and Discussion}

The synthetic protocol involved the two-step transformations. First, the reaction of one-pot Michael- $O$-alkylation pertaining bromination and base-mediated cyclization was employed to construct a furan ring. ${ }^{26-28)}$ Second, the resulting 2-acetyl furanonaphthoquinone was subjected to methylation via Grignard's reaction to form an isopropyl alcohol side chain (Chart 3). Under this strategy, lawsone (7a) was used as the starting material and was treated with an effective Michael acceptor, such as methyl vinyl ketone (8a), pen-1-en-3-one (8b), and methyl vinyl sulfone $(\mathbf{8 c})$ to obtain the desired furanonaphthoquinones $\mathbf{5 a}-\mathbf{f}$ at a yield of $12-57 \%$. During base-mediated cyclization, refluxing gave furans $\mathbf{5 b}$ and $\mathbf{e}$, while heating at $60^{\circ} \mathrm{C}$ furnished $\mathbf{5 c}$ as the major product. For the preparation of 5f, initial optimizations were examined with methyl vinyl sulfone (8c), but only low yields were obtained. Next, the resulting furanonaphthoquinones $\mathbf{5 b}$ and $\mathbf{c}$ were reacted with methyl magnesium bromide to convert their acetyl group to isopropyl alcohol, which gave an acceptable yield. Under this condition, 5a was synthesized at a gram-scale, with a yield of up to $19 \%$ yield.

The desired avicequinone C (5a), 2,3-dihydronaphtho[2,3$b$ ] furan analogues (5c and $\mathbf{d}$ ), and furanonaphthoquinone analogues $(\mathbf{5 b}, \mathbf{e}$, and $\mathbf{f})$ were characterized by standard spectroscopic analyses. Spectroscopic data of $\mathbf{5 a}, \mathbf{b}, \mathbf{d}$, and $\mathbf{f}$ were matched with the reported natural furanonaphthoquinone structures of avicequinone $\mathrm{C},{ }^{20)}$ napabucasin, ${ }^{29)}( \pm)$-stenocarpoquinone $\mathrm{B},{ }^{30)}$ and avicequinone $\mathrm{B},{ }^{31)}$ respectively.

Next, all synthetic avicequinone $C$ analogues $\mathbf{5 a}-\mathbf{f}$, quinone 6 and naphthoquinones $7 \mathbf{a}$ and $\mathbf{b}$ were evaluated for their in vitro cytotoxicity and steroid $5 \alpha$-reductase inhibitory activities using the HaCaT cell line. The results would verify the importance of the furanonaphthoquinone moiety, which could be a key pharmacophore for the inhibition of $5 \alpha$-reductase activity.

As the results shown in Table 1, 5a and its synthetic furanonaphthoquinone analogues $(\mathbf{5} \mathbf{b}-\mathbf{f})$ exhibited an in vitro $\mathrm{HaCaT}$ cellular toxicity in the range of $2.66-155.79 \mu \mathrm{M}$. The most potent cytotoxic compound in this series was $\mathbf{5 b}$ 


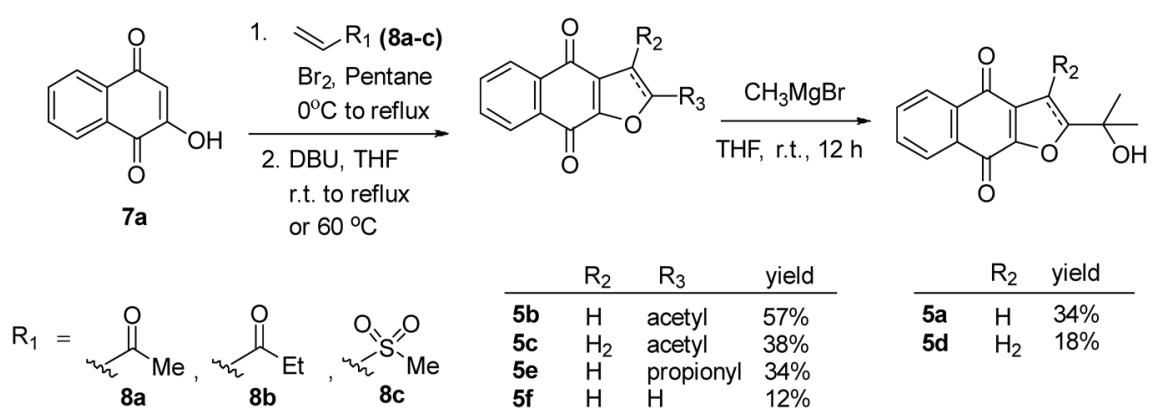

r.t.: room temperature.

Chart 3. Synthesis of Avicequinone C (5a) and Analogues (5b-f)

Table 1. HaCaT Cell-Based MTT Assay of Avicequinone C Analogues $(\mathbf{5 a}-\mathbf{f})$, Quinone $\mathbf{6}$ and Naphthoquinones $7 \mathbf{a}$ and $\mathbf{b}^{a)}$

\begin{tabular}{|c|c|c|c|}
\hline Compound & $\begin{array}{c}\text { Cytotoxicity } \\
\text { LC }_{50} \pm \text { S.D. }(\mu \mathrm{M})\end{array}$ & Compound & $\begin{array}{c}\text { Cytotoxicity } \\
\text { LC }_{50} \pm \text { S.D. }(\mu \mathrm{M})\end{array}$ \\
\hline $5 \mathbf{a}$ & $28.06 \pm 1.94$ & $5 f$ & $25.09 \pm 2.37$ \\
\hline $5 \mathbf{b}$ & $2.66 \pm 0.57$ & 6 & $>200$ \\
\hline $5 c$ & $2.92 \pm 0.48$ & $7 \mathbf{a}$ & $>200$ \\
\hline $5 d$ & $155.79 \pm 1.58$ & $7 \mathbf{b}$ & $>200$ \\
\hline $5 e$ & $3.94 \pm 0.62$ & & \\
\hline
\end{tabular}

a) Cytotoxicities were examined at $24 \mathrm{~h}$.

$\left(\mathrm{LC}_{50}=2.66 \mu \mathrm{M}\right)$, which is a furanonaphthoquinone containing a conjugated structure with an acetyl group at the furan ring. We observed that $\mathbf{5 b}$ was 10 -fold more cytotoxic than $\mathbf{5 a}$ $\left(\mathrm{LC}_{50}=28.06 \mu \mathrm{M}\right)$, which contains an isopropanol substituent at the furan ring. Additionally, $\mathbf{5 b}$ showed a broadly similar cytotoxic level to $\mathbf{5 c}\left(\mathrm{LC}_{50}=2.92 \mu \mathrm{M}\right)$ and $\mathbf{5 e}\left(\mathrm{LC}_{50}=3.94 \mu \mathrm{M}\right)$, which have a 2,3-dihydrofuran ring and a one-carbon longer propionic group at furan ring, respectively. Without the substituent at furan ring, $\mathbf{5 f}\left(\mathrm{LC}_{50}=25.09 \mu \mathrm{M}\right)$ displayed equal $\mathrm{HaCaT}$ cellular toxicity to $\mathbf{5 a}$. The loss of both the electron withdrawing group and conjugated system by having a 2,3-dihydrofuran moiety and isopropanol substituent, 5d appeared to tremendously reduce cytotoxicity of the compound. Interestingly, 5d showed the lowest cytotoxicity $\left(\mathrm{LC}_{50}=155.79 \mu \mathrm{M}\right)$ among compounds in this series against $\mathrm{HaCaT}$ cell line. This observation was similar to the cytotoxic results of $\mathbf{6}, \mathbf{7 a}$, and b; the quinone and naphthoquinones without the furan ring, which showed no toxicity at $200 \mu \mathrm{M}$ against the $\mathrm{HaCaT}$ cell line. In this way, we speculated that furanonaphthoquinone moiety and the electron withdrawing substituent at the furan ring might play a role in the cell viability against the $\mathrm{HaCaT}$ cell line.

Next, avicequinone $\mathrm{C}$ and synthetic analogues (5a-f) along with synthetic precursor (7a) and the non-furanonaphthoquinone compounds (6 and $7 \mathbf{b}$ ) were preliminary screened for their steroid $5 \alpha$-reductase type 1 inhibitory activity using the $\mathrm{HaCaT}$ cells for steroid $5 \alpha$-reductase type 1 expression to convert testosterone (1) to dihydrotestrosteron (2) in conjugation with the non-radioactive HPTLC method for the detection of $2 .^{20)}$ In this work, the HaCaT cells were cultured and treated with all nine test compounds including $\mathbf{5 a}-\mathbf{f}, \mathbf{6}, \mathbf{7 a}$, and $\mathbf{b}$ using the highest concentration, which no cell death more than half population was observed. Aqueous medium of each experiment was collected and partitioned with ethyl

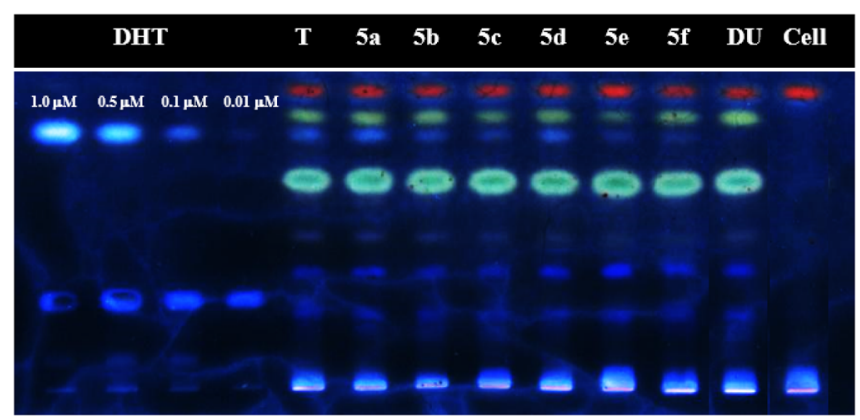

Fig. 1. Preliminary Screening of Steroid $5 \alpha$-Reductase Inhibitory Activity with HPTLC Analysis of Avicequinone C Analogues

$\mathrm{T}$ refers to testosterone (1) and DHT refers to dihydrotestosterone (2). 5a, d, and f at $5 \mu \mathrm{M} ; \mathbf{b}, \mathbf{c}$, and e at $0.5 \mu \mathrm{M}$; and dutasteride (DU, 4) at $20 \mu \mathrm{M}$ were employed as positive control in this experiment.

acetate for extracting the remaining $\mathbf{1}$, which was added as an enzyme substrate and the resulting $\mathbf{2}$, the steroid $5 \alpha$-reductase product. The steroid $5 \alpha$-reductase activity was then evaluated based upon the amount of $\mathbf{2}$ by HPTLC using a mixture of cyclohexane-ethyl acetate-triethylamine $(1.5: 1: 0.1, \mathrm{v} / \mathrm{v} / \mathrm{v})$ as the mobile phase. Then, 1 and $\mathbf{2}$ were visualized under $366 \mathrm{~nm}$ on a phosphoric acid staining TLC plate. We found that the furanonaphthoquinone analogues $(\mathbf{5 a}-\mathbf{f})$ enabled to inhibit the activity of steroid $5 \alpha$-reductase type 1 (Fig. 1).

Furthermore, the steroid $5 \alpha$-reductase type 1 inhibitory activity of furanonaphthoquinones $\mathbf{5 a}-\mathbf{f}$, along with quinone $\mathbf{6}$, synthetic precursor 7a (lawsone), and natural naphthoquinone 7b (lapachol) were evaluated for their $\mathrm{IC}_{50}$ profiles. HaCaT cells were treated with various non-cytotoxic concentrations of $\mathbf{5 a}-\mathbf{f}, \mathbf{6}, 7 \mathbf{a}$, and $\mathbf{b}$ that were chosen based on cytotoxicity obtained at $24 \mathrm{~h}$ (Table 1). As shown in Fig. 2 and Table 2, furanonaphthoquinones $\mathbf{5 a}-\mathbf{f}$ exhibited the inhibitory activity in the range of $0.20-9.63 \mu \mathrm{M}$. It was found that both furanonaphthoquinones 5a and $\mathbf{f}$ displayed similar degree of inhibition $\left(\mathrm{IC}_{50}=4.45\right.$ and $4.26 \mu \mathrm{M}$, respectively). The less cytotoxic 5d; the 2,3-dihydrofuran analog having isopropanol substituent resemble to $\mathbf{5 a}$, showed 2 -fold less inhibitory activity toward steroid $5 \alpha$-reductase type $1\left(\mathrm{IC}_{50}=9.63 \mu \mathrm{M}\right)$, relative to 5a. The group of highly toxic analogues $\mathbf{5 c}$ and $\mathbf{e}$, which contained the ketone substituents adjacent to 2,3-dihydrofuran and furan moieties possessed strong steroid $5 \alpha$-reductase type 1 inhibitory profile, approximately 4 - and 22-fold more inhibitory activity $\left(\mathrm{IC}_{50}=1.21\right.$ and $\left.0.20 \mu \mathrm{M}\right)$, respectively, relative to 5a. The steroid $5 \alpha$-reductase inhibitory activity of the most potent cytotoxic $\mathbf{5 b}$ could not be examined due to the death of 

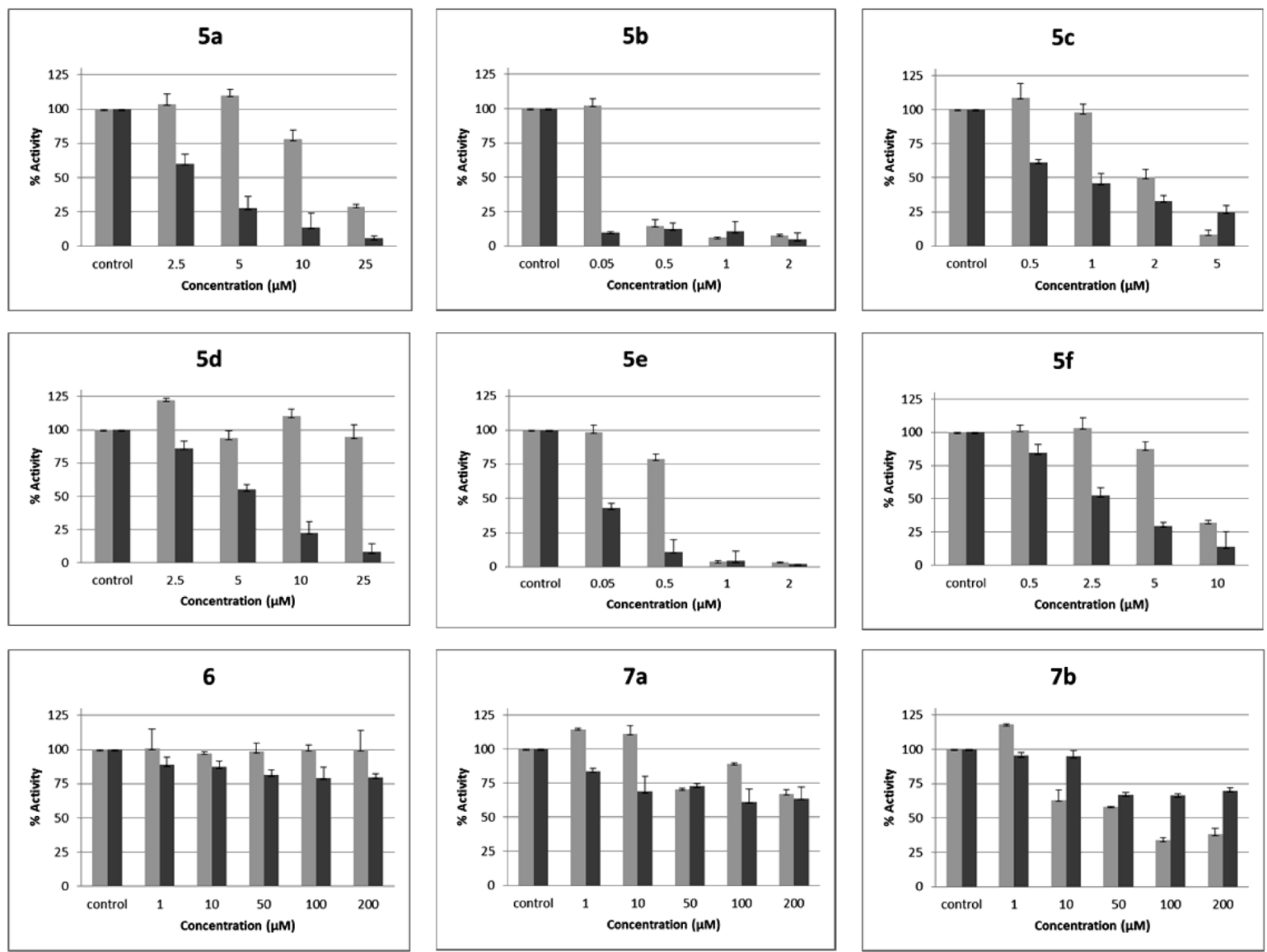

Cell viability

Enzyme activity

Fig. 2. Cell Viability and Steroid $5 \alpha$-Reductase Enzyme Activity of Avicequinone C Analogues (5a-f), Quinone $\mathbf{6}$ and Naphthoquinones $7 \mathbf{a}$ and $\mathbf{b}$ toward HaCaT Cell-Based Assay at $48 \mathrm{~h}$

Table 2. Steroid $5 \alpha$-Reductase Inhibitory Activity $\left(\mathrm{IC}_{50}\right)$ via $\mathrm{HaCaT}$ CellBased Assay at $48 \mathrm{~h}$ of Avicequinone C Analogues (5a-f), Quinone 6, and Naphthoquinones $\mathbf{7 a}$ and $\mathbf{b}^{a)}$

\begin{tabular}{cccc}
\hline \hline Compound & $\begin{array}{c}5 \alpha \text {-Reductase inhibitory } \\
\text { activity } \mathrm{IC}_{50} \pm \text { S.D. }(\mu \mathrm{M})\end{array}$ & Compound & $\begin{array}{c}5 \alpha \text {-Reductase inhibitory } \\
\text { activity } \mathrm{IC}_{50} \pm \text { S.D. }(\mu \mathrm{M})\end{array}$ \\
\hline $\mathbf{5 a}$ & $4.45 \pm 0.42$ & $\mathbf{5 f}$ & $4.26 \pm 0.38$ \\
$\mathbf{5 b}$ & n.d. $^{b}$ & $\mathbf{6}$ & $>200$ \\
$\mathbf{5 c}$ & $1.21 \pm 0.12$ & $\mathbf{7 a}$ & $>200$ \\
$\mathbf{5 d}$ & $9.63 \pm 0.78$ & $\mathbf{7 b}$ & $>200$ \\
$\mathbf{5 e}$ & $0.20 \pm 0.03$ & & \\
\hline
\end{tabular}

a) Dutasteride $(20 \mu \mathrm{M})$ was employed as a control and provided complete inhibition. b) n.d. refers to not determined.

$\mathrm{HaCaT}$ cell line. Thus, the cell-free enzyme activity assay will be required for further study of $\mathbf{5} \mathbf{b}$. Interestingly, the non-furanonaphthoquinones $\mathbf{6}, 7 \mathbf{a}$ and $\mathbf{b}$ were found to be incapable to inhibit the steroid $5 \alpha$-reductase activity. According to the results, it seems that compounds with furanonaphthoquinone such as $\mathbf{5 a}-\mathbf{f}$ showed a promising $5 \alpha$-reductase inhibitory activity, which could potentially serve as a new $5 \alpha$-reductase inhibitor that will be further studied and developed for the treatment of androgenic disorder such as prostate cancer, benign prostatic hyperplasia, acne, hirsutism, and androgenic alopecia. ${ }^{2)}$

To rational the structure-activity relationship of furanonaphthoquinone analogues $(\mathbf{5 a}-\mathbf{f})$ toward steroid $5 \alpha$-reductase type 1 , the docking studies were performed. The in silico three-dimensional (3D) $5 \alpha$-reductase type 1-NADPH binary complex was prepared based on the previously reported strategy. ${ }^{19)}$ The binding pattern and intermolecular interaction of all furanonaphthoquinone analogues (5a-f) were predicted (Fig. 3). The furanonaphthoquinones $\mathbf{5 a}-\mathbf{e}$ were resided closely adjacent to NADPH and likely interacted with Tyr95 of the in silico $5 \alpha$-reductase type 1 as well as NADPH. Note that the oxygen atom of the substituent at the furan ring was in correspondence to the reported result of $4 .{ }^{19)}$ The binding site of furanonaphthoquinone $\mathbf{5 f}$ to the $5 \alpha$-reductase type 1-NADPH binary complex was slightly different from the others; however its oxygen atom on quinone motif was able to form a hydrogen bond with Tyr95. The molecular docking results emphasized the importance of the substituents at furan ring and quinone moieties; however the structure-activity relationship might not be intensively concluded here. The further in vitro study is required to identify the inhibitory mechanism of furanonaphthoquinone toward steroid $5 \alpha$-reductase inhibition.

\section{Conclusion}

In conclusion, the synthesis of six furanonaphthoquinone analogues (5a-f) was achieved. All synthetic furanonaphthoquinones $(\mathbf{5 a}-\mathbf{f})$, the commercial available quinone $\mathbf{6}$, naphthoquinone $\mathbf{7 a}$, employed as a synthetic starting material in this work, and the known natural naphthoquinone $\mathbf{7 b}$ were examined for their anti-proliferative and steroid $5 \alpha$-reductase 


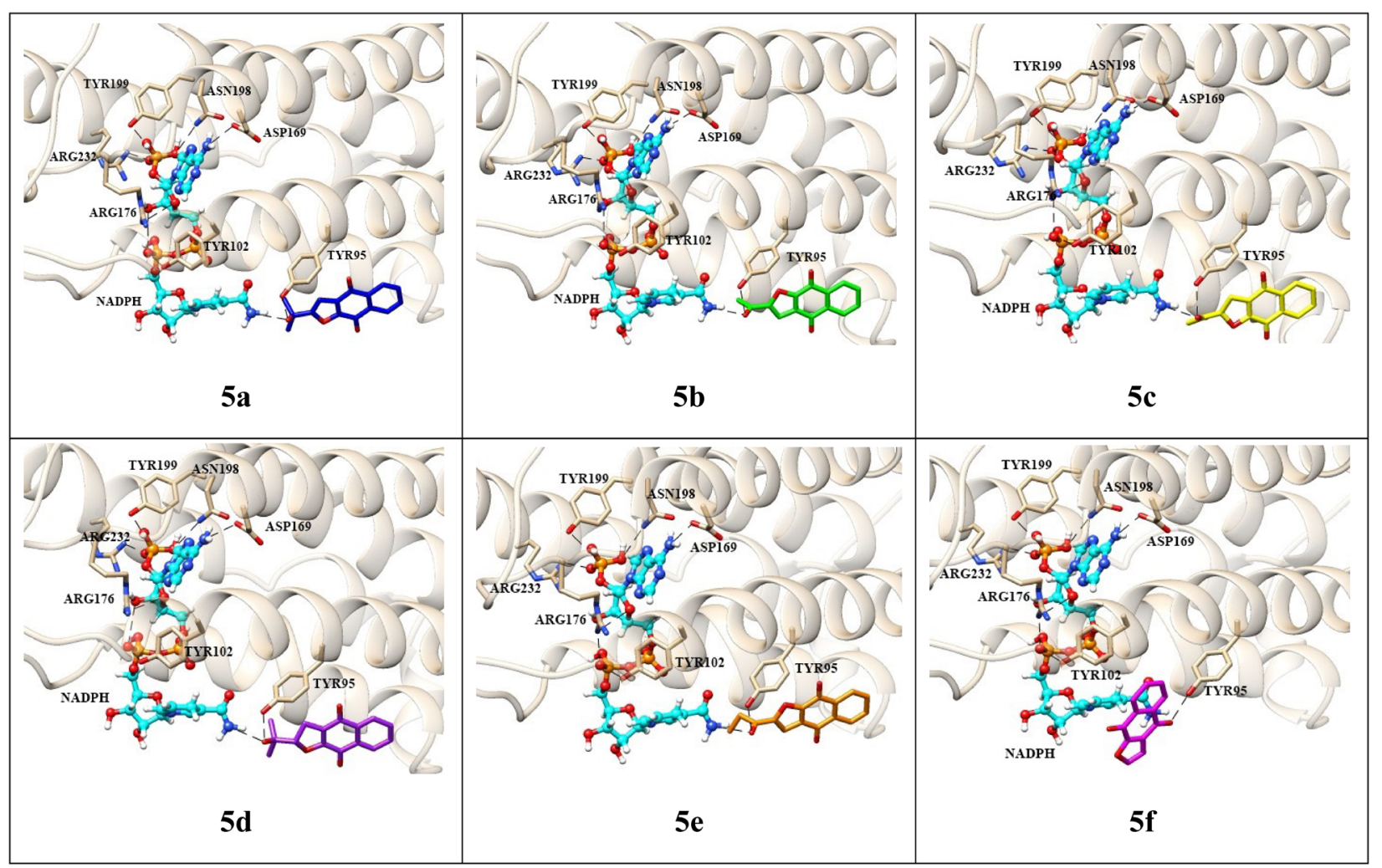

Fig. 3. Molecular Docking Results of Furanonaphthoquinone Analogues (5a-f) with the In Silico Three-Dimensional 5 $\alpha$-Reductase Type 1-NADPH Binary Complex

type 1 inhibitory activity against the HaCaT cell line. The steroid $5 \alpha$-reductase type 1 inhibitory activity was measured based on the production of $5 \alpha$-dihydrotestosterone (2) via the non-radioactive HPTLC procedure. The series of furanonaphthoquinones $(\mathbf{5 a}-\mathbf{f})$ showed interesting cellular toxicity and enabled to inhibit the activity of steroid $5 \alpha$-reductase type 1 of the HaCaT cell line with the improved inhibitory activity, relative to avicequinone $\mathrm{C}(\mathbf{5 a})$; the natural furanonaphthoquinone isolated from Avicennia marina. To our surprise, 5e; the most cytotoxic compound among all synthetic furanonaphthoquinones having a propionic substituent, exhibited approximately 22 -fold more potent toward the steroid $5 \alpha$-reductase inhibitory activity, comparing to $\mathbf{5 a}$. Considering the results between the in vitro steroid $5 \alpha$-reductase inhibitory activity and molecular docking of the in silico 3D steroid $5 \alpha$-reductase type 1-NADPH binary complex, we concluded that the furanonaphthoquinone moiety and the substituent at furan ring are the potential pharmacophores for the steroid $5 \alpha$-reductase inhibitory activity. New chemical feature for $5 \alpha$-reductase inhibitor displaying a stronger $5 \alpha$-reductase inhibition than $\mathbf{5 a}$ was discovered. Further studies in molecular dynamics along with in vitro experiments could provide insight information regarding the biological mechanisms toward the steroid $5 \alpha$-reductase metabolism. Finally, a new series of furanonaphthoquinone will be developed as the promising steroid $5 \alpha$-reductase inhibitors for the treatment of androgenic disorders such as androgenic alopecia.

\section{Experimental}

Materials Reactions were performed in oven-dried glassware and magnetically stirred under an inert atmosphere using a syringe tube equipped with an argon or nitrogen balloon.
Room temperature was $25^{\circ} \mathrm{C}$. Commercial solvents and reagents were used as received. Anhydrous solvents were dried over $4 \AA$ molecular sieves. All reactions were monitored by TLC using aluminium silica gel 60 F254 (Merck). IR spectra were measured on a Fourier transform (FT)-IR spectrometer, PerkinElmer, Inc. (U.S.A.) ${ }^{1} \mathrm{H}$ - and ${ }^{13} \mathrm{C}-\mathrm{NMR}$ spectra were obtained on a Bruker Avance DPX-300 FT-NMR spectrometer. ${ }^{1} \mathrm{H}-\mathrm{NMR}$ chemical shifts $(\delta)$ and coupling constants $(J)$ were given in $\mathrm{ppm}$ and $\mathrm{Hz}$, respectively. Deuterated chloroform $\left(\mathrm{CDCl}_{3}\right)$ served as an internal standard for both ${ }^{1} \mathrm{H}$ - and ${ }^{13} \mathrm{C}-\mathrm{NMR}$ spectra at 7.26 and $77.0 \mathrm{ppm}$, respectively. Mass spectra were recorded on a microTOF Bruker Daltonics mass spectrometer.

Synthesis of Avicequinone C (5a) To a stirred solution of methyl vinyl ketone (8a) (2.5 equiv, $7.18 \mathrm{mmol}, 0.6 \mathrm{~mL}$ ) in $6 \mathrm{~mL}$ of pentane was added a solution of bromine $(2.6$ equiv, $7.46 \mathrm{mmol}, 0.3 \mathrm{~mL}$ ) in $3 \mathrm{~mL}$ of pentane at $-15^{\circ} \mathrm{C}$ ( $\mathrm{NaCl}$ mixed ice bath). The reaction was stirred for $10 \mathrm{~min}$. Then, all volatiles were evaporated under reduced pressure to yield the crude 1,2-dibromobutan-2-one, which was further used in the next step without purification. Next, lawsone (7a) (1 equiv, $2.87 \mathrm{mmol}, 500 \mathrm{mg}$ ) was weighted into a $50-\mathrm{mL}$ oven-dried round-bottomed flask and dissolved in $15 \mathrm{~mL}$ of tetrahydrofuran (THF), followed by the addition of 1,8-diazabicyclo[5.4.0] undec-7-ene (DBU) (3.7 equiv, $10.62 \mathrm{mmol}, 1.6 \mathrm{~mL}$ ), giving a red solution. The reaction was stirred at $0^{\circ} \mathrm{C}$ (ice bath) under a nitrogen atmosphere for $20 \mathrm{~min}$. A freshly prepared solution of 1,2-dibromobutan-2-one in $3 \mathrm{~mL}$ of THF was added and the ice bath was immediately removed. The reaction mixture was gradually warmed up and was then heated to reflux for $5 \mathrm{~h}$. Another portion of DBU (0.52 equiv, $1.49 \mathrm{mmol}, 0.2 \mathrm{~mL}$ ) was added and the reaction 
mixture was continuously refluxed and stirred for another $3 \mathrm{~h}$. The reaction was then quenched by the addition of saturated aqueous ammonium chloride and extracted with chloroform ( $25 \mathrm{~mL} \times 3$ times). The organic extracts were combined, washed with water and saturated sodium chloride, dried over anhydrous $\mathrm{Na}_{2} \mathrm{SO}_{4}$, filtered and evaporated under reduced pressure to obtain the crude product. Purification of the crude reaction by silica gel column chromatography eluting with dichloromethane-hexanes $(4: 1, \mathrm{v} / \mathrm{v})$ provided 2-acetylnaphtho[2,3-b]furan-4,9-dione (5b) as a yellow powder at a yield of $420 \mathrm{mg}$ (57\%). ${ }^{1} \mathrm{H}-\mathrm{NMR}\left(\mathrm{CDCl}_{3}, 300 \mathrm{MHz}\right) \delta: 8.26(1 \mathrm{H}, \mathrm{m}, 5-\mathrm{H})$, $8.25(1 \mathrm{H}, \mathrm{m}, 8-\mathrm{H}), 7.81(1 \mathrm{H}, \mathrm{m}, 6-\mathrm{H}), 7.81(1 \mathrm{H}, \mathrm{m}, 7-\mathrm{H}), 7.61$ $(1 \mathrm{H}, \mathrm{s}, 3-\mathrm{H}), 2.67(3 \mathrm{H}, \mathrm{s}, 11-\mathrm{H}) ;{ }^{13} \mathrm{C}-\mathrm{NMR}\left(\mathrm{CDCl}_{3}, 100 \mathrm{MHz}\right)$ $\delta$ : 187.5 (C-10), 179.7 (C-4), 173.9 (C-9), 155.5 (C-9a), 152.9 (C-2), 134.4 (C-6), 134.3 (C-7), 133.1 (C-8a), 132.6 (C-4a), 130.7 (C-3a), 127.4 (C-8), 127.2 (C-5), 112.3 (C-3), 26.8 (C-11); IR (KBr) 3113, 3014, 2854, 1690, 1674, 1581, 1359, 1285, 1259, 1224, 1197, 977, 875, $717 \mathrm{~cm}^{-1}$; high resolution (HR)MS-electrospray ionization (ESI) $\mathrm{m} / \mathrm{z} 263.0321\left([\mathrm{M}+\mathrm{Na}]^{+}\right.$, calcd for $\mathrm{C}_{14} \mathrm{H}_{8} \mathrm{O}_{4} \mathrm{Na}^{+}$263.0315). The resulting $\mathbf{5 b}$ (1 equiv, $0.208 \mathrm{mmol}, 50 \mathrm{mg}$ ) was weighted into a $50-\mathrm{mL}$ oven-dried round-bottomed flask and dissolved in $20 \mathrm{~mL}$ of THF. The reaction mixture was stirred at room temperature under an argon atmosphere. Methyl magnesium bromide $(3.0 \mathrm{M}$ in diethylether, 6 equiv, $1.249 \mathrm{mmol}, 0.4 \mathrm{~mL}$ ) was added to the reaction mixture. The reaction mixture was stirred at room temperature for $6 \mathrm{~h}$. After completion, the reaction mixture was quenched by the addition of aqueous hydrochloric acid $(2 \mathrm{~N}, 15 \mathrm{~mL})$ and stirred at room temperature for $30 \mathrm{~min}$. The reaction mixture was then evaporated under reduced pressure until about $10 \mathrm{~mL}$ of reaction mixture remained. The reaction mixture was added water $(5 \mathrm{~mL})$, extracted with ethyl acetate $(35 \mathrm{~mL} \times 3$ times) and washed with saturated sodium chloride $(20 \mathrm{~mL})$. The organic layers were collected, dried over anhydrous $\mathrm{Na}_{2} \mathrm{SO}_{4}$ and filtered. The reaction mixtures were evaporated to obtain the crude compound. Purification by silica gel column chromatography using ethyl acetate-hexanes ( $3: 7, \mathrm{v} / \mathrm{v})$ as eluent provided avicequinone $\mathrm{C}(\mathbf{5 a})$ as a brown solid at a yield of $17.2 \mathrm{mg}(34 \%) .{ }^{1} \mathrm{H}-\mathrm{NMR}\left(\mathrm{CDCl}_{3}, 300 \mathrm{MHz}\right)$ $\delta: 8.21(1 \mathrm{H}, \mathrm{m}, 5-\mathrm{H}), 8.18(1 \mathrm{H}, \mathrm{m}, 8-\mathrm{H}), 7.75(1 \mathrm{H}, \mathrm{m}, 6-\mathrm{H})$, $7.75(1 \mathrm{H}, \mathrm{m}, 7-\mathrm{H}), 6.82(1 \mathrm{H}, \mathrm{s}, 3-\mathrm{H}), 1.69(3 \mathrm{H}, \mathrm{s}, 11-\mathrm{Ha}), 1.69$ $(3 \mathrm{H}, \mathrm{s}, 11-\mathrm{Hb}) ;{ }^{13} \mathrm{C}-\mathrm{NMR}\left(\mathrm{CDCl}_{3}, 100 \mathrm{MHz}\right) \delta$ : $180.8(\mathrm{C}-4)$, 173.4 (C-9), 167.9 (C-9a), 151.8 (C-2), 133.9 (C-7), 133.8 (C-6), 133.0 (C-8a), 132.5 (C-4a), 131.3 (C-3a), 126.9 (C-5), 127.0 (C-8), 102.6 (C-3), 69.4 (C-10), 29.7 (C-11a), 28.8 (C-11b); IR (KBr) 3532, 3388, 3178, 3121, 2986, 2926, 1682, 1665, 1586, 1376, 1231, 1165, 1154, 968, 954, $724 \mathrm{~cm}^{-1}$; HR-MS-ESI $\mathrm{m} / \mathrm{z}$ $279.0635\left([\mathrm{M}+\mathrm{Na}]^{+}\right.$, calcd for $\mathrm{C}_{15} \mathrm{H}_{12} \mathrm{O}_{4} \mathrm{Na}^{+}$279.0628).

Synthesis of $5 \mathbf{c}$ and $\mathbf{d}$ Dihydrofuran $5 \mathbf{c}$ was prepared by following the synthesis of $\mathbf{5} \mathbf{b}$. The reaction temperature during the DBU-mediated cyclization was controlled at $60^{\circ} \mathrm{C}$ to obtain 2-acetyl-2,3-dihydronaphtho[2,3-b]furan-4,9-dione (5c) as a yellow powder at a yield of $263 \mathrm{mg}(38 \%) .{ }^{1} \mathrm{H}-\mathrm{NMR}\left(\mathrm{CDCl}_{3}\right.$, $300 \mathrm{MHz}) \delta: 8.08(1 \mathrm{H}, \mathrm{m}, 5-\mathrm{H}), 8.08(1 \mathrm{H}, \mathrm{m}, 8-\mathrm{H}), 7.72(1 \mathrm{H}$, m, 6-H), $7.72(1 \mathrm{H}, \mathrm{m}, 7-\mathrm{H}), 5.27(1 \mathrm{H}, \mathrm{t}, J=9.6 \mathrm{~Hz}, 2-\mathrm{H}), 3.42$ $(2 \mathrm{H}, \mathrm{dd}, J=2.1,10.8 \mathrm{~Hz}, 3-\mathrm{H}), 2.39(3 \mathrm{H}, \mathrm{s}, 11-\mathrm{H}) ;{ }^{13} \mathrm{C}-\mathrm{NMR}$ $\left(\mathrm{CDCl}_{3}, 100 \mathrm{MHz}\right) \delta: 204.6$ (C-10), 181.7 (C-4), 177.2 (C-9), 159.2 (C-9a), 134.4 (C-7), 133.3 (C-6), 132.8 (C-4a), 131.4 (C-8a), 126.4 (C-8), 126.2 (C-5), 123.8 (C-3a), 87.1 (C-2), 30.1 (C-3), 26.5 (C-11); Characterization of carbonyl groups of quinone at C-4 and C-9 were based on reported data ${ }^{27)}$; IR ( $\mathrm{KBr}$ )
3093, 2949, 2860, 1737, 1682, 1652, 1631, 1591, 1395, 1375, 1361, 1242, 1195, 963, $722 \mathrm{~cm}^{-1}$; HR-MS-ESI $m / z 281.0223$ $\left([\mathrm{M}+\mathrm{K}]^{+}\right.$, calcd for $\mathrm{C}_{14} \mathrm{H}_{10} \mathrm{O}_{4} \mathrm{~K}^{+}$281.0211). The resulting 5c was subjected to methylation using a similar reaction condition as the preparation of $\mathbf{5 a}$, to give 2-(2-hydroxypropan-2-yl)-2,3dihydronaphtho[2,3- $b$ ]furan-4,9-dione (5d) as a yellow powder at a yield of $8.8 \mathrm{mg}(18 \%) .{ }^{1} \mathrm{H}-\mathrm{NMR}\left(\mathrm{CDCl}_{3}, 300 \mathrm{MHz}\right) \delta: 8.08$ $(1 \mathrm{H}, \mathrm{m}, 5-\mathrm{H}), 8.08(1 \mathrm{H}, \mathrm{m}, 8-\mathrm{H}), 7.70(1 \mathrm{H}, \mathrm{m}, 6-\mathrm{H}), 7.70(1 \mathrm{H}$, m, 7-H), $4.85(1 \mathrm{H}, \mathrm{t}, J=9.9 \mathrm{~Hz}, 2-\mathrm{H}), 3.17(2 \mathrm{H}, \mathrm{d}, J=9.9 \mathrm{~Hz}$, $3-\mathrm{H}), 1.40$ (3H, s, 11-Ha), $1.28(3 \mathrm{H}, \mathrm{s}, 11-\mathrm{Hb}) ;{ }^{13} \mathrm{C}-\mathrm{NMR}$ $\left(\mathrm{CDCl}_{3}, 100 \mathrm{MHz}\right) \delta$ : 182.2 (C-4), 177.7 (C-9), 159.9 (C-9a), 134.2 (C-4a), 133.0 (C-6), 133.0 (C-7), 131.5 (C-8a), 126.3 (C-8), 126.1 (C-5), 125.0 (C-3a), 71.7 (C-10), 92.1 (C-2), 29.7 (C-3), 25.8 (C-11a), 24.1 (C-11b); Characterization of carbonyl groups of quinone at C-4 and C-9 were based on reported data $^{27)}$; IR (KBr) 3436, 2925, 2854, 1686, 1655, 1632, 1597, 1464, 1376, 1200, 1079, $970 \mathrm{~cm}^{-1}$; HR-MS-ESI $\mathrm{m} / \mathrm{z} 281.0793$ $\left([\mathrm{M}+\mathrm{Na}]^{+}\right.$, calcd for $\mathrm{C}_{15} \mathrm{H}_{14} \mathrm{O}_{4} \mathrm{Na}^{+}$281.0784).

Synthesis of $5 \boldsymbol{e}$ The propionyl containing furanonaphthoquinone 5e was prepared by following the synthesis of 5b. Pen-1-en-3-one (8b) was employed as the Michael- $O$ alkylation electrophile to give 2-propionylnaphtho[2,3-b]furan-4,9-dione (5e) as a yellow powder at a yield of $259 \mathrm{mg}$ (34\%). ${ }^{1} \mathrm{H}-\mathrm{NMR}\left(\mathrm{CDCl}_{3}, 300 \mathrm{MHz}\right) \delta: 8.26(1 \mathrm{H}, \mathrm{m}, 5-\mathrm{H})$, $8.23(1 \mathrm{H}, \mathrm{m}, 8-\mathrm{H}), 7.81(1 \mathrm{H}, \mathrm{m}, 6-\mathrm{H}), 7.81(1 \mathrm{H}, \mathrm{m}, 7-\mathrm{H}), 7.61$ $(1 \mathrm{H}, \mathrm{s}, 3-\mathrm{H}), 3.06(2 \mathrm{H}, \mathrm{q}, J=7.5,14.7 \mathrm{~Hz}, 11-\mathrm{H}), 1.26(3 \mathrm{H}, \mathrm{t}$, $J=7.2 \mathrm{~Hz}, 12-\mathrm{H}) ;{ }^{13} \mathrm{C}-\mathrm{NMR}\left(\mathrm{CDCl}_{3}, 100 \mathrm{MHz}\right) \delta: 190.8(\mathrm{C}-10)$, 179.8 (C-4), 173.9 (C-9), 155.4 (C-9a), 152.7 (C-2), 134.4 (C-7), 134.3 (C-6), 133.1 (C-8a), 132.6 (C-4a), 130.7 (C-3a), 127.3 (C-5), 127.3 (C-8), 112.0 (C-3), 32.6 (C-11), 7.4 (C-12); IR (KBr) 3385, 3115, 2978, 2878, 1698, 1672, 1579, 1567, 1354, 1219, 958, $721 \mathrm{~cm}^{-1}$; HR-MS-ESI $\mathrm{m} / z 277.0464\left([\mathrm{M}+\mathrm{Na}]^{+}\right.$, calcd for $\mathrm{C}_{15} \mathrm{H}_{10} \mathrm{O}_{4} \mathrm{Na}^{+}$277.0471).

Synthesis of $\mathbf{5 f}$ Methyl vinyl sulfone (8c) (1.0 equiv, $4.71 \mathrm{mmol}, 500 \mathrm{mg}$ ) was weighted into a $50-\mathrm{mL}$ oven-dried round-bottomed flask and dissolved in dichloromethane $(10 \mathrm{~mL})$. The reaction mixture was stirred at room temperature under an argon atmosphere. Bromine (1.5 equiv, $7.07 \mathrm{mmol}$, $0.2 \mathrm{~mL}$ ) was slowly added into the reaction mixture giving the dark orange solution. The reaction mixture was heated to reflux for $6 \mathrm{~h}$. The reaction mixture was then concentrated to yield a sticky residue, dissolved in THF $(20 \mathrm{~mL})$ and cooled at $0^{\circ} \mathrm{C}$ in an ice-bath under an argon atmosphere. DBU (1.5 equiv, $7.07 \mathrm{mmol}, 1.1 \mathrm{~mL}$ ) was slowly added dropwise over $20 \mathrm{~min}$. The reaction mixture was stirred for $30 \mathrm{~min}$ at $0^{\circ} \mathrm{C}$ in an ice-bath under an argon atmosphere. Lawsone (7a) (1.0 equiv, $4.71 \mathrm{mmol}, 820.2 \mathrm{mg}$ ) was added and another portion of DBU (1.5 equiv, $7.07 \mathrm{mmol}, 1.1 \mathrm{~mL}$ ) was slowly added dropwise over $20 \mathrm{~min}$. The reaction mixture was stirred for $30 \mathrm{~min}$ at $0^{\circ} \mathrm{C}$ in an ice-bath under an argon atmosphere. The ice-bath was then removed. The reaction was warmed up to room temperature and heated to reflux for $6 \mathrm{~h}$. The reaction was then concentrated under reduced pressure and the residue was dissolved in dichloromethane $(100 \mathrm{~mL})$, washed with water $(100 \mathrm{~mL})$ and saturated aqueous ammonium chloride $(100 \mathrm{~mL})$. The organic layer was separated and the aqueous layer was extracted with dichloromethane $(50 \mathrm{~mL} \times 3$ times). The combined organic layer was dried over anhydrous $\mathrm{Na}_{2} \mathrm{SO}_{4}$ and concentrated to obtain the crude product. The crude product was purified over silica gel column chromatography using dichloromethane-hexanes $(3: 1, \mathrm{v} / \mathrm{v})$ as eluent to provide 
naptho[2,3-b]furan-4,9-dione (5f) as a pale yellow solid at a yield of $69 \mathrm{mg}(12 \%) .{ }^{1} \mathrm{H}-\mathrm{NMR}\left(\mathrm{CDCl}_{3}, 300 \mathrm{MHz}\right) \delta: 8.22(1 \mathrm{H}$, m, 5-H), $8.22(1 \mathrm{H}, \mathrm{m}, 8-\mathrm{H}), 7.77(1 \mathrm{H}, \mathrm{m}, 6-\mathrm{H}), 7.77(1 \mathrm{H}, \mathrm{m}$, 7-H), $7.77(1 \mathrm{H}, \mathrm{d}, J=1.5 \mathrm{~Hz}, 2-\mathrm{H}), 7.01(1 \mathrm{H}, \mathrm{d}, J=1.5 \mathrm{~Hz}, 3-\mathrm{H})$; ${ }^{13} \mathrm{C}-\mathrm{NMR}\left(\mathrm{CDCl}_{3}, 100 \mathrm{MHz}\right) \delta: 180.6$ (C-4), 173.6 (C-9), 152.7 (C-9a), 148.6 (C-2), 132.5 (C-4a), 134.0 (C-7), 133.9 (C-6), 133.2 (C-8a), 130.5 (C-3a), 127.1 (C-8), 127.0 (C-5), 108.7 (C-3); IR (KBr) 3142, 2853, 1683, 1585, 1566, 1478, 1365, 1206, 1182, 952, $714 \mathrm{~cm}^{-1}$; HR-MS-ESI $\mathrm{m} / z 221.0212\left([\mathrm{M}+\mathrm{Na}]^{+}\right.$, calcd for $\mathrm{C}_{12} \mathrm{H}_{6} \mathrm{O}_{3} \mathrm{Na}^{+}$221.0215). Spectroscopic data of $\mathbf{5 f}$ were matched with reported data of avicequinone B. ${ }^{31)}$

Molecular Docking The 3D predicted structures of $5 \alpha$-reductase type 1 was achieved by following the reported protocol. ${ }^{32}$ ) The homology modeling strategies involved automated homologous protein template searching by SWISSMODEL. The isoprenylcysteine carboxyl methyltransferase (ICMT, PDB code: 4A2N) was automatically selected as a homologous protein template for building the in silico $3 \mathrm{D}$ structure of $5 \alpha$-reductase type 1. Ramachandran plot for standard in silico structure evaluation, active site identification by docking study of finasteride (3) and dutasteride (4) using AutoDock Vina, $\left.{ }^{25}\right)$ transmembrane site prediction via Discovery Studio 2.5, and docking of the reported $5 \alpha$-reductase inhibitors to confirmed the active site and protein-ligand interactions. The 3D structures of all studied compounds were generated by the Open Babel software. ${ }^{33)}$ Each compound was then docked into the resulting in silico $5 \alpha$-reductase type 1-NADPH binary complex with 100 independent runs using AutoDock Vina. ${ }^{25}$ Then, each ligand was docked into the resulting in silico $5 \alpha$-reductase type 1-NADPH binary complex with the grid box near the position of NADPH (center $x=0.487$, center $y=36.43$, and center $z=96.802$ ) and the grid box size is of $38 \times 18 \times 16 \AA^{3}$. The docking calculations of $5 \alpha$-reductase type 1 were performed with 100 runs and the average results were analyzed.

In Vitro Cell Viability 3-(4,5-Dimethylthiazol-2-yl)-2,5diphenyltetrazolium Bromide (MTT) Assay HaCaT cells were grown in Dulbecco's modified Eagle's medium (DMEM) containing $10 \%(\mathrm{v} / \mathrm{v})$ fetal bovine serum (FBS) and 1\% (v/v) antibiotic-antimycotic solution at $37^{\circ} \mathrm{C}$ in humidified atmosphere of $5 \% \mathrm{CO}_{2}$ in a T-75 flask. The cells were grown until at $80 \%$ confluency, and then subcultured. Cells were seeded at an initial cell density of 5000 cells/well onto 96-well plates and allowed to adhere overnight. After $24 \mathrm{~h}$, the cells were individually treated with a series of synthetic avicequinone $\mathrm{C}$ and analogues (5a-f), 2,5-dihydroxy-1,4-benzoquinone (6), and natural naphthoquinones including lawsone (7a) and lapachol (7b). Dutasteride (4) was used as a positive control. Each test compound was prepared as the serial concentrations in DMEM containing 0.1\% (v/v) dimethyl sulfoxide (DMSO). DMEM was used as a negative control. Cells were incubated at $37^{\circ} \mathrm{C}$ in atmosphere of $5 \% \mathrm{CO}_{2}$ for $24 \mathrm{~h}$. Cell viability was measured by the MTT assay. ${ }^{34)}$ In the presence of viable cells, cells were incubated with $100 \mu \mathrm{L}$ of a solution of MTT in DMEM medium at a concentration of $0.5 \mathrm{mg} / \mathrm{mL}$. The tests plates were incubated at $37^{\circ} \mathrm{C}$ under $5 \% \mathrm{CO}_{2}$ atmosphere for $3 \mathrm{~h}$. Then, all liquid medium were removed. The resulting formazan crystals were dissolved in DMSO $(100 \mu \mathrm{L})$. The absorbance was measured at $540 \mathrm{~nm}$ using a VICTOR3 multilabel plate reader (PerkinElmer, Inc.). Experiments with triplicate data were performed to obtain mean cell viability. The mean \pm standard deviations (S.D.) were obtained from three independent experiments. $\mathrm{The} \mathrm{IC}_{50}$ values were calculated according to the cell viability ratios.

HaCaT-Based Steroid 5 $\alpha$-Reductase Inhibitory Assay $\mathrm{HaCaT}$ cells were seeded at a cell density of $2 \times 10^{5}$ cells/well onto 6-well plates, and allowed to adhere for $24 \mathrm{~h}$. Testosterone ( 1 , substrate) and $5 \alpha$-dihydrotestosterone (2, product) were employed as the internal standard and enzyme-activity control, respectively. Dutasteride (4) at $20 \mu \mathrm{M}$ was used as a positive control. The overall volume of each well was $2 \mathrm{~mL}$. DMEM (1 mL) was added into each standard and control wells. A solution of testosterone (1, substrate) at $50 \mu \mathrm{M}(1 \mathrm{~mL})$ in DMEM containing $1 \%(\mathrm{v} / \mathrm{v})$ DMSO was added in each test well. The final concentration of 1 was $25 \mu \mathrm{M}$. Cells were treated with a serial solution at non-cytotoxicity of each test compound that was dissolved in DMEM containing $1 \%(\mathrm{v} / \mathrm{v})$ DMSO $(1 \mathrm{~mL})$. Each test was repeated in triplicate. After incubating in humidified atmosphere of $\mathrm{CO}_{2}$ at $37^{\circ} \mathrm{C}$ for $48 \mathrm{~h}$, the cell culture medium was collected and the remaining viable cells were determined by MTT assay as previously explained. The aqueous medium was extracted with ethyl acetate $(1.5 \mathrm{~mL})$, vigorously shaken, centrifuged at $10000 \mathrm{rpm}$ for $5 \mathrm{~min}$, and the $1 \mathrm{~mL}$ of ethyl acetate layer was kept. The extraction was repeated two times. The resulting ethyl acetate extracts that consisted of the remaining $\mathbf{1}$ and the resulting 2 were combined and air dried at room temperature. The crude extract was then reconstituted with $20 \mu \mathrm{L}$ of methanol and $8 \mu \mathrm{L}$ of the resulting methanol solution was spotted onto a TLC silica gel 60 F254 aluminum plate using TLC sample loader (CAMAG Linomat 5, Switzerland). The TLC plate was developed using a mixture of cyclohexane-ethyl acetate-trimethylamine $(1.5: 1: 0.1, \mathrm{v} / \mathrm{v} / \mathrm{v})$ as a mobile phase. Then, the developed TLC plate was stained with a solution of $42.5 \%$ phosphoric acid in ethanol and heated at $120^{\circ} \mathrm{C}$ for $20 \mathrm{~min}$ for visualization. Visual detection of $5 \alpha$-dihydrotestosterone (2) at $366 \mathrm{~nm}$ was captured using the TLC scanner (CAMAG TLC Scanner 3, Switzerland). The band intensity of $\mathbf{2}$ was measured by the Image $\mathbf{J}$ software and the inhibitory activity was calculated according to the inhibition ratios. In order to avoid false positive result, the cell viability of the treated cells was determined. The test compound at concentration showing more than $50 \%$ cell viability was further considered for $\mathrm{IC}_{50}$ calculation. The $\mathrm{IC}_{50}$ values were calculated according to the inhibition ratios. The mean \pm S.D. were obtained from three independent experiments.

Acknowledgments This research has been supported by the Ratchadaphiseksomphot Endowment Fund 2013 of Chulalongkorn University (CU-56-334-HR) to S.C., the PERDO's Center of Excellence on Medical Biotechnology (CEMB) program to W.D. and the Thailand Research Fund (IRG5780008) to T.R. We are also grateful to the Cell-Based Drug and Health Product Development Research Unit and Department of Pharmacology and Physiology, Faculty of Pharmaceutical Sciences, Chulalongkorn University for technical assistance.

Conflict of Interest The authors declare no conflict of interest.

Supplementary Materials The online version of this article contains supplementary materials. See supplementary 
materials for ${ }^{1} \mathrm{H}$ - and ${ }^{13} \mathrm{C}-\mathrm{NMR}$ spectra and HPTLC chromatograms of $\mathbf{5 a}-\mathbf{f}$.

\section{References}

1) Russell D. W., Wilson J. D., Annu. Rev. Biochem., 63, 25-61 (1994). 2) Azzouni F., Godoy A., Li Y., Mohler J., Adv. Urol., 2012, 1-18 (2012).

3) Jain R., De-Eknamkul W., Expert Opin. Ther. Targets, 18, 787-806 (2014).

4) Titus M. A., Gregory C. W., Ford O. H. 3rd, Schell M. J., Maygarden S. J., Mohler J. L., Clin. Cancer Res., 11, 4365-4371 (2005).

5) Jain R., De-Eknamkul W., Expert Opin. Ther. Targets, 18, 787-806 (2014).

6) Godoy A., Kawinski E., Li Y., Oka D., Alexiev B., Azzouni F., Titus M. A., Mohler J. L., Prostate, 71, 1033-1046 (2011).

7) Marks L. S., Adv. Urol., 6, S11-S21 (2004).

8) Randall V. A., The endocrine control of hair follicle. Hair growth and disorder. Springer-Verlag Berlin Heidelberg, Germany, 2008.

9) Kelly Y., Blanco A., Tosti A., Drugs, 76, 1349-1364 (2016).

10) Birch M. P., Messenger A. G., EJD, 11, 309-314 (2001).

11) Steiner J. F., Clin. Pharmacokinet., 30, 16-27 (1996).

12) Mella J. M., Perret M. C., Manzotti M., Catalano H. N., Guyatt G., Arch. Dermatol., 146, 1141-1150 (2010).

13) Olsen E. A., Hordinsky M., Whiting D., Stough D., Hobbs S., Ellis M. L., Wilson T., Rittmaster R. S., Dutasteride Alopecia Research Team, J. Am. Acad. Dermatol., 55, 1014-1023 (2006)

14) Eun H. C., Kwon O. S., Yeon J. H., Shin H. S., Kim B. Y., Ro B. I., Cho H. K., Sim W. Y., Lew B. L., Lee W. S., Park H. Y., Hong S. P., Ji J. H., J. Am. Acad. Dermatol., 63, 252-258 (2010).

15) Gubelin Harcha W., Barboza Martínez J., Tsai T.-F., Katsuoka K., Kawashima M., Tsuboi R., Barnes A., Ferron-Brady G., Chetty D., J. Am. Acad. Dermatol., 70, 489-498.e3 (2014).

16) Aggarwal S., Thareja S., Verma A., Bhardwaj T. R., Kumar M., Steroids, 75, 109-153 (2010).

17) Yao Z., Xu Y., Zhang M., Jiang S., Nicklaus M. C., Liao C., Bioorg. Med. Chem. Lett., 21, 475-478 (2011).

18) Min-Rui O., Jun-Qian L., Chinese Journal of Structure Chemistry, 31, 1618-1626 (2012).

19) Karnsomwan W., Rungrotmongkol T., De-Eknamkul W., Chamni
S., Med. Chem. Res., 25, 1049-1056 (2016).

20) Jain R., Monthakantirat O., Tengamnuay P., De-Eknamkul W., Molecules, 19, 6809-6821 (2014).

21) Jain R., Monthakantirat O., Tengamnuay P., De-Eknamkul W., BMC Complement. Altern. Med., 16, 18 (2016).

22) Seiffert K., Seltmann H., Fritsch M., Zouboulis C. C., Horm. Metab. Res., 39, 141-148 (2007).

23) Izgi A., Turglu M., Akyildrum B., Celen S., Celik N., American Journal of Dermatology and Venereology, 3, 23-29 (2014).

24) Thiboutot D., Knaggs H. G., Gilliland K., Lin G., Dermatology, 196, 38-42 (1998).

25) Trott O., Olson A. J., J. Comput. Chem., 31, 455-461 (2010).

26) Hagiwara H., Sato K., Nishino D., Hoshi T., Suzuki T., Ando M., J. Chem. Soc., 2001, 2496-2957 (2001).

27) Jiang Z., Wang A., Hu H., Xu J., Hu Y., Li X., Ye Y., Wang J., Li Q., (2012) [The International Patent System].

28) Aswathanarayanappa C., Bheemappa E., Bodke Y. D., Bhovi V. K., Ningegowda R., Shivakumar M. C., Peethambar S. K., Telkar S., Med. Chem. Res., 22, 78-87 (2013).

29) Peraza-Sánchez S. R., Chávez D., Chai H. B., Shin Y. G., Garcia R., Mejía M., Fairchild C. R., Lane K. E., Menendez A. T., Farnsworth N. R., Cordell G. A., Pezzuto J. M., Kinghorn A. D., J. Nat. Prod., 63, 492-495 (2000).

30) Ribeiro C. M. R., de Souza P. P., Ferreira L. D. M., Pereira S. L. Martins I. d. S., Epifanio R. d. A., Costa-Lotufo L. V., Jimenez P. C., Pessoa C., de Moraes M. O., Lett. Org. Chem., 8, 347-351 (2011).

31) Tseng C.-H., Chen Y.-L., Yang S.-H., Peng S., Cheng C.-M., Han C.-H., Lin S.-R., Tzeng C.-C., Bioorg. Med. Chem., 18, 5172-5182 (2010).

32) Karnsomwan W., Rungrotmongkol T., De-Eknamkul W., Chamni S., Med. Chem. Res., 25, 1049-1056 (2016).

33) O’Boyle N. M., Banck M., James C. A., Morley C., Vandermeersch T., Hutchison G. R., J. Chemometr., 3, 33 (2011).

34) Riss T. L. M., R. A., Niles, A. L., Benink, H. A., Worzella, T. J., Minor, L. "Assay Guidance Manual [Internet]," ed. by Sittampalam G. S., Coussens N. P., Nelson H., Eli Lilly \& Company and the National Center for Advancing Translational Sciences, Bethesda, MD, 2004. 